\title{
THE CORRELATION OF TEACHER PERSONALITY COMPETENCE WITH DISCIPLINE OF GRADE 6 STUDENT
}

\author{
Siti Animah ${ }^{1}$, Sholeh Hidayat ${ }^{2}$, Lukman Nulhakim ${ }^{3}$ \\ 1,2,3 Universitas Sultan Ageng Tirtayasa, Serang, Indonesia \\ ISitianimah316@gmail.com, 25holeh.hidayat@untirta.ac.id, ${ }^{3}$ lukman.nulhakim@untirta.ac.id
HUBUNGAN KOMPETENSI KEPRIBADIAN GURU DENGAN DISIPLIN SISWA KELAS VI

\begin{tabular}{|c|c|}
\hline ARTICLE INFO & ABSTRACT \\
\hline $\begin{array}{l}\text { Submitted: } \\
15 \text { Juli } 2020 \\
15^{\text {th }} \text { July } 2020\end{array}$ & $\begin{array}{l}\text { Abstract: The background of this research is the low awareness of discipline. This study aims to } \\
\text { determine the correlation of teacher personality competence with student discipline and how much the } \\
\text { correlation between teacher competency and student discipline. The research method used was } \\
\text { correlational. This research was conducted in grade } 6 \text { SDN Majalaya with the sample of } 30 \text { students. } \\
\text { Data collection techniques were Likert scale questionnaires that had been tested for validity and } \\
\text { reliability. Based on the results of the correlation analysis test obtained a correlation coefficient of } 0.61 \\
\text { with a significance of } 0.000 \text {. The significance value obtained was } 0.000 .0 .000<0.05 \text { thus there was a } \\
\text { correlation between the teacher's personal competence and student discipline. }\end{array}$ \\
\hline
\end{tabular}

Keywords: personality competence, discipline

Accepted:

25 Agustus 2020

$25^{\text {th }}$ August 2020

Published:

31 Agustus 2020

$31^{\text {th }}$ August 2020
Abstrak: Latar belakang penelitian ini adalah rendahnya kesadaran akan kedisiplinan.. Penelitian ini bertujuan untuk mengetahui hubungan kompetensi kepribadian guru dengan disiplin siswa dan berapa besar hubungan kompetensi guru dengan disiplin siswa. Metode penelitian yang digunakan yaitu korelasional. Penelitian ini dilaksanakan di kelas VI SDN Majalaya dengan sampel 30 siswa. Teknik pengumpulan data yaitu angket skala Likert yang telah diuji validitas dan reliabilitas. Berdasarkan hasil uji analisis korelasi didapatkan koefisien korelasi sebesar 0,61 dengan signifikansi sebesar 0,000. Nilai signifikansi yang didapat adalah 0.000. $0.000<0.05$ dengan demikian terdapat hubungan antara kompetensi kepribadian guru dengan disiplin siswa.

Kata kunci: kompetensi kepribadian, disiplin

\section{CITATION}

Animah, S., Hidayat, S., \& Nulhakim, L. (2020). The Correlation of Teacher Personality Competence with Discipline of Grade 6 Student. Primary: Jurnal Pendidikan Guru Sekolah Dasar, 9(4), 520-526. DOI: http://dx.doi.org/10.33578/jpfkip.v9i4.7981.

\section{PENDAHULUAN}

Pembelajaran merupakan suatu proses interaksi antara peserta didik dengan pendidik sebagai wahana menanamkan nilai-nilai atau pengetahuan yang dipandang perlu sebagai upaya mendewasakan para generasi untuk siap hidup dimasa yang akan datang secara berkualitas. Selanjutnya pembelajaran yang dilakukan peserta didik dan pendidik diharapkan menghasilkan nilainilai kepribadian yang baik agar kepribadian yang baik dapat dilakukan sampai akhir hayat.

Salah satu keberhasilan pembelajaran tidak terlepas dari peran seorang guru. Guru sebagai tenaga pendidik dengan tugas utamanya mengajar, memiliki karakteristik kepribadian yang sangat berpengaruh terhadap keberhasilan siswa. Kepribadian adalah suatu tingkah laku ciri khas yang harus dimiliki setiap individu. Kepribadian yang mantap dari sosok seorang guru akan memberikan teladan yang baik terhadap anak didik maupun masyarakatnya, sehingga akan tampil sebagai sosok yang patut "digugu" (ditaati nasihat/ucapan/perintahnya) dan "ditiru" (dicontoh sikap dan perilakunya).

Salah satu kompetensi yang harus dimiliki 
guru yaitu kompetensi kepribadian. Menurut Taufik (2013:44) kepribadian guru adalah pribadi yang mantap atau akhlak mulia, sebagai suri tauladan, atau figur moral bagi peserta didik. Dengan demikian seorang guru harus menguasai kompetensi kepribadian agar memberikan efek yang positif kepada siswa, apabila seorang guru memberikan efek negatif kepada siswa maka siswa akan mengikuti karena seorang guru merupakan model yang akan akan diikuti oleh siswa.

Dalam proses pembelajaran, setiap guru mempunyai keinginan agar siswanya berhasil dalam mencapai hasil belajar. Untuk itu, diperlukan penegakan disiplin bagi siswa yang melanggar tata tertib yang berlangsung di sekolah, siswa diharapkan dapat berprilaku baik dan berhasil dalam proses pembelajaran. Di sekolah menjadikan disiplin sebagai syarat dalam pembentukan sikap dan perilaku siswa. Dengan disiplin akan tumbuh kepatuhan, kemandirian, keteraturan, menumbuhkan percaya diri, menumbuhkan sikap percaya diri dan peduli terhadap orang lain (Widyaningsih: 2015).

Adapun usaha-usaha dalam proses meningkatkan kedisiplinan belajar siswa adalah salah satunya melalui teladan seorang guru. Perbuatan dan tindakan lebih besar pengaruhnya dibandingkan hanya sekedar dengan kata-kata. Oleh karena itu contoh dan teladan disiplin kepala sekolah dan para guru sangat berpengaruh terhadap kedisiplinan siswa. Mereka lebih mudah meniru

\section{KAJIAN TEORETIS}

Setiap manusia yang ada di dunia, pasti memiliki kompetensi. Baik itu kompetensi yang ada dalam dirinya yang dibawa sejak lahir maupun kompetensi yang muncul sejalan dengan kehidupan yang dijalaninya. Manusia pasti memiliki kemampuan atau kompetensi yang berbeda, dengan demikian setiap orang akan melakukan hal atau tindakan yang beragam sesuai dengan keahlian atau kemampuan yang ada di dalam dirinya. Semakin tinggi kemampuan seseorang, maka semakin mudahlah untuk melakukan segala tindakan dan perbuatan yang diinginkannya. Kompetensi guru adalah seperangkat penguasaan kemampuan yang harus dari apa yang mereka lihat, dibandingkan hanya sekedar mendengar. Seperti halnya seorang anak yang akan meniru kepribadian ibu dan bapaknya, dalam masalah pendidikan juga siswa akan dipengaruhi oleh lingkungan pendidikannya salah satunya adalah guru. Guru merupakan pelopor pertama dalam menanamkan disiplin kepada peserta didik. Setidaknya guru harus lebih dahulu memulai menerapkan pada dirinya untuk mempunyai pribadi yang disiplin, arif, dan berwibawa.

Berdasarkan hasil observasi di kelas VI SDN Majalaya, ditemukan beberapa siswa yang kurang kesadaran akan pentingnya disiplin misalnya terlambat datang ke sekolah, istirahat tidak pada waktunya dan masih banyak siswa yang tidak memakai seragam sesuai aturan. Selanjutnya dilihat dari gurunya, guru terlihat memiliki kompetensi kepribadian yang baik karena guru datang tepat waktu, pribadi yang dewasa serta memiliki emosi yang stabil.

Dari pemaparan di atas, penelitian ini dilakukan untuk mengetahui apakah terdapat hubungan kompetensi kepribadian guru dengan disiplin siswa dan berapa besar hubungan kompetensi kepribadian guru dengan disiplin siswa. Dengan demikan diharapkan guru-guru dapat meningkatkan kualitas kompetensi kepribadian agar disiplin siswa semakin meningkat.

ada dalam diri guru agar dapat mewujudkan kinerjanya secara tepat dan efektif (Kunandar, 2011:55).

Menurut Jamil, S (2013: 106-107) kompetensi kepribadian merupakan kemampuan personal yang mencerminkan kepribadian yang mantap, stabil, dewasa, arif, berwibawa, menjadi teladan bagi siswa dan berakhlak mulia.

Kepribadian sebagai suatu kebulatan yang terdiri dari aspek-aspek jasmaniah dan rohaniah bersifat dinamik dalam hubungannya dengan lingkungan, khas (unik), berbeda dengan orang lain dan berkembang dipengaruhi oleh faktor-faktor 
yang berasal dari dalam diri dan luar diri (Nursiti,N. 2013: 4).

Ada empat kompetensi yang harus dikuasi oleh guru yaitu kompetensi pedagogik, kompetensi kepribadian, kompetensi profesional dan kompetensi sosial. Salah satu kompetensi yang harus dikuasi oleh guru adalah kompetensi kepribadian. Kepribadian guru adalah pribadi yang mantap atau akhlak mulia, sebagai suri tauladan, atau figur moral bagi peserta didik (Taufik, 2013:44).

Disiplin merupakan suatu tindakan yang menunjukkan perilaku tertib dan patuh pada berbagai ketentuan dan peraturan. Pendidikan karakter disiplin merupakan hal penting untuk diperhatikan dalam rangka membina karakter seseorang. Berbekal nilai karakter disiplin akan mendorong tumbuhnya nilai-nilai karakter baik lainnya, seperti tanggung jawab, kejujuran, kerjasama, dan sebagainya.

Disiplin berarti kontrol penguasaan diri terhadap impuls yang tidak diinginkan atau proses mengarahkan impuls pada suatu cita-cita atau

\section{METODE PENELITIAN}

Penelitian ini dilakukan di SDN Majalaya tahun ajaran 2019/2020. Dalam penelitian ini, peneliti menggunakan pendekatan kuantitatif dengan metode korelasional. Metode korelasional berfungsi untuk mencari gambaran sederhana tentang hubungan diantara variabel. Penelitian ditujukan untuk meneliti sejauh mana variabel pada satu faktor berkaitan dengan variabel pada faktor lainnya. tujuan tertentu untuk mencapai dampak yang lebih besar (Husdarta 2010 : 110).

Banyak sekali faktor yang dapat menanamkan disiplin, disiplin dapat ditanaman karena adanya faktor-faktor yang mempengaruhinya. Ada empat faktor yang mempengaruhi disiplin yaitu kesadaran diri, pengikutan dan ketaatan, alat pendidikan dan hukuman (Tulus, 2017:48).

Pelanggaran Disiplin dapat terjadi karena hal-hal berikut: 1) Disiplin sekolah yang direncanakan dengan baik dan mantap; 2) Perencanaan yang baik, tetapi implementasinya kurang baik dan kurang dimonitor oleh kepala sekolah; 3) Penerapan disiplin yang tidak konsisten dan tidak konsenkuen; 4) Kebijakan kepala sekolah yang belum memprioritaskan peningkatan dan pemantapan disiplin sekolah; 5) Kurang keja sama dan dukungan guru-guru dalam perencanaan dan implementasi disiplin sekolah; 6) Kurangnya dukungan dan partisipasi orang tua dalam menangani disiplin sekolah hukuman (Tulus, 2017:53).

Populasi dalam penelitian ini sebanyak 54 siswa. Sedangkan sampel yang digunakan yaitu 30 siswa kelas VI SDN Majalaya.

Adapun teknik pengumpulan data yang digunakan yaitu angket. Instrumen pada penelitian ini berupa angket kompetensi guru dan disiplin siswa yang diujikan kepada siswa kelas VI.

Tabel 1. Kisi-kisi Angket Kepribadian Guru

\begin{tabular}{|c|c|c|c|c|}
\hline No & Indikator & Sub Indikator & No pernyataan & $\begin{array}{c}\text { Sifat } \\
\text { pernyataan }\end{array}$ \\
\hline 1 & Bersikap Disiplin & $\begin{array}{l}\text { Disiplin dalam waktu dan } \\
\text { perbuatan }\end{array}$ & $5,6,7,8,9,10,14,15,16$ & $\begin{array}{l}\text { Positif } 4 \\
\text { Negatif } 5\end{array}$ \\
\hline 2. & Berwibawa & $\begin{array}{l}\text { Pribadi yang mantap dan } \\
\text { stabil }\end{array}$ & $11,12,13,19$ & Positif 4 \\
\hline & & Pribadi yang dewasa & 17,18 & Positif 2 \\
\hline 3. & $\begin{array}{l}\text { Santun } \\
\text { perbuatan }\end{array}$ & $\begin{array}{l}\text { Bersikap santun kepada } \\
\text { orang lain }\end{array}$ & $20,1,2,3,4,8$ & $\begin{array}{l}\text { Positif } 3 \\
\text { Negatif } 2\end{array}$ \\
\hline
\end{tabular}




\section{PRIMARY: JURNAL PENDIDIKAN GURU SEKOLAH DASAR}

VOLUME 9 NOMOR 4 AGUSTUS 2020

ISSN: 2303-1514 | E-ISSN: 2598-5949

Jumal Pendidikan Guru Sekolah Dasar

DOI : http://dx.doi.org/10.33578/jpfkip.v9i4.7981

https://primary.ejournal.unri.ac.id/index.php/JPFKIP

\begin{tabular}{|c|c|c|c|c|}
\hline 4. & Pemaaf & $\begin{array}{l}\text { Memaafkan siswa dalam } \\
\text { pembelajaran }\end{array}$ & 21 & Negatif 1 \\
\hline \multirow[t]{2}{*}{5 . } & $\begin{array}{l}\text { Memiliki motif yang } \\
\text { tinggi untuk terus }\end{array}$ & Mengikuti kegiatan ilmiah & 22,23 & $\begin{array}{l}\text { Positif } 1 \\
\text { Negatif } 1\end{array}$ \\
\hline & & $\begin{array}{ll}\text { Rajin } & \text { memperbarui } \\
\text { keilmuannya } & \end{array}$ & 24,25 & $\begin{array}{l}\text { Positif } 1 \\
\text { Negatif } 1\end{array}$ \\
\hline
\end{tabular}

Tabel 2. Kisi-kisi angket disiplin Siswa

\begin{tabular}{|c|c|c|c|c|}
\hline No & Indikator & Sub Indikator & $\begin{array}{c}\text { No } \\
\text { pernyataan }\end{array}$ & $\begin{array}{c}\text { Sifat } \\
\text { pernyataan }\end{array}$ \\
\hline \multirow[t]{3}{*}{1} & $\begin{array}{l}\text { Ketaatan terhadap } \\
\text { belajar }\end{array}$ & $\begin{array}{l}\text { Mengulang kembali materi yang } \\
\text { diajarkan guru }\end{array}$ & 9,4 & $\begin{array}{l}\text { Positif } 1 \\
\text { Negatif } 1\end{array}$ \\
\hline & & $\begin{array}{l}\text { Mengikuti } \\
\text { ekstakulikuler }\end{array}$ & $18,6,7,8$ & $\begin{array}{l}\text { Positif } 3 \\
\text { Negatif } 1\end{array}$ \\
\hline & & $\begin{array}{l}\text { Membawa perlengkapan belajar } \\
\text { sesuai pelajaran }\end{array}$ & 12,13 & $\begin{array}{l}\text { Positif } 1 \\
\text { Negatif } 1\end{array}$ \\
\hline 2. & $\begin{array}{l}\text { Ketaatan terhadap tugas-tugas } \\
\text { pelajaran }\end{array}$ & $\begin{array}{l}\text { Mengerjakan dan mengumpulkan } \\
\text { tugas tepat waktu }\end{array}$ & 19,15 & $\begin{array}{l}\text { Positif } 1 \\
\text { Negatif } 1\end{array}$ \\
\hline 3. & $\begin{array}{l}\text { Ketaatan terhadap } \\
\text { penggunaan fasilitas belajar }\end{array}$ & $\begin{array}{l}\text { Menggunakan perpus dengan } \\
\text { baik } \\
\text { Penggunaan buku siswa }\end{array}$ & $\begin{array}{c}1,2,10,11,17 \\
16\end{array}$ & $\begin{array}{l}\text { Positif } 3 \\
\text { Negatif } 2 \\
\text { Positif } 1\end{array}$ \\
\hline 4. & $\begin{array}{lr}\text { Ketaatan } & \text { belajar } \\
\text { menggunakan waktu datang } \\
\text { dan pulang }\end{array}$ & $\begin{array}{l}\text { Masuk dan keluar sekolah tepat } \\
\text { waktu }\end{array}$ & $3,5,20,14$ & $\begin{array}{l}\text { Positif } 3 \\
\text { Negatif } 1\end{array}$ \\
\hline 5. & $\begin{array}{l}\text { Disiplin dalam kehidupan } \\
\text { sehari-hari }\end{array}$ & $\begin{array}{l}\text { Menggunakan waktu dengan } \\
\text { sangat baik }\end{array}$ & $\begin{array}{l}21,22,23 \\
24,25\end{array}$ & $\begin{array}{l}\text { Positif } 3 \\
\text { Negatif } 2 \\
\end{array}$ \\
\hline
\end{tabular}

Teknik analisis data menggunakan korelasi Product Moment. Setelah diujikannya uji prasyarat data yaitu uji normalitas dan uji homogenitas. Hipotesis dalam penelitian ini dirumuskan sebagai berikut:

Ho $=$ Tidak terdapat hubungan kompetensi kepribadian guru dengan disiplin siswa kelas VI SDN Majalaya

$\mathrm{H} \alpha=$ Terdapat hubungan kompetensi kepribadian guru dengan disiplin siswa kelas VI SDN Majalaya

\section{HASIL DAN PEMBAHASAN}

Penelitian ini dilakukan sekali pertemuan yaitu ketika memberikan angket kompetensi hasil angket ompetensi kepribadian guru dan kepribadian guru dan disiplin siswa. Berikut ini didiplin siswa.

Tabel 3. Rekapitulasi Hasil Angket Kompetensi Kepribadian Guru dan Disiplin siswa

\begin{tabular}{ccc}
\hline Statistik & Kompetensi Guru & Disiplin \\
\hline Banyak Siswa (N) & 30 & 30 \\
Nilai Terendah & 69 & 72 \\
Nilai Tertinggi & 83 & 84 \\
Rata-rata & 77.2 & 78.6 \\
\hline
\end{tabular}


Sebelum dilakukan uji hipotesis, dilakukan uji prasyarat data berupa uji normalitas dan uji homogenitas. Uji normalitas data dilakukan untuk mengetahui apakah data yang diperoleh dalam penelitian ini berdistribusi normal atau tidak. Dalam penelitian ini uji normalitas data dilakukan dengan menggunaknan uji Shapiro-Wilks. Tujuan uji homogenitas dalam penelitian ini yaitu untuk mengetahui homogen atau tidaknya populasi yang digunakan pada sebaran data. Berikut ini hasil perhitungan uji normalitas dan uji homogenitas disajikan menggunakan tabel.

Tabel 4. Hasil Uji Normalitas Angket Kompetensi Kepribadian Guru dan Disiplin siswa

\begin{tabular}{lcccc}
\hline \multicolumn{1}{c}{ Data } & Jenis Uji & Wilk Hitung & Wilk Tabel & kesimpulan \\
\hline Kompetensi Guru & Shapiro Wilk & 0.94 & 0.92 & Normal \\
Disiplin Siswa & & 0.95 & 0.92 & Normal \\
\hline
\end{tabular}

Berdasarkan data di atas, data kompetensi guru memperoleh Wilk hitung 0.94 dengan Wilk tabel 0.92. Maka Wilk hitung > Wilk tabel sehingga data berdistribusi normal. Adapun untuk data disiplin siswa memperoleh Wilk hitung 0.95 dengan Wilk tabel 0.92. Maka Wilk hitung > Wilk tabel sehingga data berdistribusi normal.

Tabel 5. Hasil Uji Homogenitas Angket Kompetensi Kepribadian Guru dan Disiplin siswa

\begin{tabular}{llccc}
\hline \multicolumn{1}{c}{ Data } & Variansi & F $_{\text {hitung }}$ & $\mathbf{F}_{\text {tabel }}$ & Kesimpulan \\
\hline Kompetensi Guru & 3.98 & 1.25 & 4.18 & Homogen \\
Disiplin Siswa & 3.17 & 1.25 & 4.18 & Homogen \\
\hline
\end{tabular}

Berdasarkan data di atas, data kompetensi kepribadian guru dan disiplin siswa memperoleh $F_{\text {hitung }} 1.25$ sedangkan $F_{\text {tabel }}$ 4.18. Maka diperoleh $\mathrm{F}_{\text {hitung }} \mathrm{F}_{\text {tabel }}$ atau $1.25<4.18$ sehingga kesimpulannya adalah varians kedua data homogen.

Setelah data penelitian memenuhi uji prasyarat, peneliti melakukan analisis korelasi. Uji analisis korelasi memiliki tujuan untuk mengetahui tingkat hubungan yang terdapat pada kedua variabel yaitu variabel $\mathrm{X}$ (kompetensi kepribadian guru) dan variabel $\mathrm{Y}$ (disiplin siswa). Hasil uji analisis korelasi kedua variabel tersebut adalah sebagai berikut:

Tabel 6. Hasil Uji Analisis Korelasi

\begin{tabular}{lcc}
\hline \multicolumn{1}{c}{ Data } & Korelasi Pearson & Signifikansi \\
\hline Kompetensi Guru & 0.61 & 0.000 \\
Disiplin Siswa & 0.61 & 0.000 \\
\hline
\end{tabular}

Berdasarkan hasil uji analisis korelasi di atas, didapatkan koefisien korelasi sebesar 0.61 dengan signifikansi sebesar 0.000. Selanjutnya dilakukan pengujian hipotesis dengan membandingkan taraf signifikansi dengan nilai alpha yaitu 0.05 . Berdasarkan kaidah bahwa jika nilai signifikansi $<0.05$, maka hipotesis diterima. Nilai signifikansi yang di dapat adalah 0.000 , ini menunjukkan bahwa $0.000<0.05$ dengan demikian artinya terdapat hubungan antara kompetensi kepribadian guru dengan disiplin siswa.

Untuk mengetahui tingkat hubungan antara variabel $\mathrm{X}$ dan variabel $\mathrm{Y}$ perlu melakukan interpretasi nilai $\mathrm{r}_{\text {hitung }} \mathrm{ke}$ dalam tabel interpretasi koefisien korelasi. Nilai $r_{\text {hitung }}$ yang didapat adalah 0.61 yang berada diantara interval koefisien 0.60 0.79 , hal ini menunjukkan hubungan kompetensi 
kepribadian guru dan disiplin belajar siswa tergolong kuat.

Pengujian hipotesis pada penelitian ini menggunakan uji-t pada taraf signifikansi 5\%, hasil perhitungan uji hipotesis penelitian disajikan pada tabel berikut ini.

Tabel 7. Hasil Uji Hipotesis

\begin{tabular}{lcc}
\hline \multicolumn{1}{c}{ Data } & $\mathbf{t}_{\text {hitung }}$ & $\mathbf{t}_{\text {tabel }}$ \\
\hline Kompetensi Guru & 4.08 & 1.70 \\
Disiplin Siswa & 4.08 & 1.70 \\
\hline
\end{tabular}

Berdasarkan tabel di atas, diperoleh $\mathrm{t}_{\text {hitung }}$ senilai 4.08 dan $t_{\text {tabel }}$ senilai 1.70. Maka dapat disimpulkan bahwa $t_{\text {hitung }}>t_{\text {tabel }}$ atau $4.08>1.70$ sehingga Ho ditolak dan Ha diterima. Hal tersebut berarti bahwa terdapat hubungan kompetensi kepribadian guru dengan disiplin siswa.

Selain itu dilakukan uji determinasi, tujuan uji tersebut untuk mengetahui kontribusi variabel $\mathrm{X}$ terhadap variabel $\mathrm{Y}$. Berdasarkan hasil uji koefisien determinasi diperoleh sebesar 0.37. Hal ini menunjukkan bahwa variabel kompetensi kepribadian guru berkontribusi pada disiplin siswa sebesar $37 \%$ sedangkan sisanya dipengaruhi oleh faktor lain di luar penelitian ini.

Pengujian hipotetsis menunjukkan bahwa terdapat hubungan kompetensi kepribadian guru dengan disiplin siswa, hal ini berarti kepribadian guru sangatlah penting bagi siswa. Kepribadian adalah unsur yang menentukan keakraban hubungan guru dengan anak didik. Kepribadian guru akan tercermin pada sikap dan perbuatannya dalam membina dan membimbing siswa. Guru yang dapat memahami tentang kesulitan siswa dalam hal belajar dan kesulitan lainnya di luar masalah belajar, terutama yang bisa menghambat aktivitas belajar anak didik, maka guru tersebut akan disenangi siswanya. Sebagai teladan, guru harus memiliki kepribadian yang dapat dijadikan idola karena seluruh kehidupannya adalah figur yang paripurna. Guru dapat dikatakan sebagai mitra anak didik dalam kebaikan, karena sosok guru yang baik akan membuat siswapun menjadi baik (Djamarah, 2010:33).

Sekolah dipahami sebagai lembaga pendidikan formal. Ditempat inilah kegiatan pembelajaran berlangsung, ilmu pengetahuan dibelajarkan dan proses pembinaan kepribadian anak juga berlangsung. Dengan demikian sekolah merupakan lembaga pendidikan yang paling strategis untuk menanamkan dan membiasakan kedisiplinan. Untuk itu disiplin harus ditanamkan sedini mungkin disekolah dengan cara menerapkan tata tertib, meningkatkan anjuran atau perintah yang tegas, meningkatkan kebiasaan siswa dalam melakukan hal-hal yang baik dan bersifat tidak merugikan siswa lain (Elly, R. 2016: 43)

Saat di sekolah, figur guru merupakan pribadi kunci. Gurulah panutan utama bagi anak didik. Semua sikap dan perilaku guru akan dilihat, didengar dan ditiru oleh anak didik. Ucapan guru dalam bentuk perintah dan larangan harus dituruti oleh anak didiknya. Sikap dan perilaku anak didik berada dalam lingkaran tata tertib dan peraturan sekolah (Djamarah, 2011:105).

Dari hasil penelitian dan pembahasan yang diperoleh dalam penelitian ini, terdapat hubungan kompetensi kepribadian guru dengan disiplin siswa. Selanjutnya seorang guru harus menguasai kompetensi kepribadian guru agar dapat menjadi contoh bagi siswa. Disiplin sangatlah penting dilakukan agar pembelajaran berjalan dengan lancar. 


\section{SIMPULAN DAN REKOMENDASI}

Berdasarkan hasil penelitian yang telah dilakukan di SDN Majalaya Kabupaten Serang mengenai hubungan kompetensi kepribadian guru dengan disiplin siswa, maka memperoleh kesimpulan bahwa terdapat hubungan kompetensi kepribadian guru dengan disiplin siswa kelas VI

\section{UCAPAN TERIMA KASIH (OPTIONAL)}

Terima kasih kepada orang tua (Bapak M.Sana dan Ibu Rodiah), Bapak Prof. Dr .H. Sholeh Hidayat, M.Pd dan Dr. Lukman Nulhakim,

\section{DAFTAR PUSTAKA}

Djamarah. (2010). Guru dan Anak Didik dalam Interaksi Edukatif. Jakarta: PT. Rineka Cipta.

Djamarah. (2011). Psikologi Belajar. Jakarta: Rineka Cipta.

Elly, R. (2016). Hubungan Kedisiplinan Terhadap Hasil Belajar Siswa. Jurnal Pesona Dasar, 3(4),

43-56.

ww.jurnal.unsyiah.ac.id/PEAR/article/view/ 7540 .

Husdarta. (2010). Psikologi Olahraga. Bandung: Alfabeta.

Jamil, S. 2012.Guru Profesional. Yogyakarta: ArRuzz Media.

Kunandar. (2011). Guru Profesional. Jakarta: Raja Grafindo Persada.

Nursiti, N. 2013. Pengembangan Kepribadian Bagi Para Profesional. Dinas Pendidikan Provinsi Banten.

Taufik. M. (2013). Pengantar Pendidikan. Bandung: Mujahid Press.

Tulus, T. (2017). Peran Disiplin pada Perilaku dan Prestasi Siswa. Jakarta: PT. Grasindo.

Widyaningsih. (2015). Pengaruh Kompetensi Kepribadian Guru terhadap Disiplin siswa Kelas V SD Se-gugus I Sidoarum Godean Sleman Tahun 2015/2016. Jurnal JPGSDI, $1(3), 2$.

Ojs.upy.ac.id/ojs/index.php/JPGSDI/article/ view/313
SDN Majalaya Kabupaten Serang. Selain itu, dari perhitungan korelasi dinyatakan bahwa hubungan kompetensi kepribadian guru dengan disiplin siswa kelas VI SDN Majalaya Kabupaten Serang adalah sebesar 0.61 yang termasuk kategori kuat.

M.Pd yang telah memberiakan masukan dan seluruh pihak yang telah memberikan bantuan selama berlangsungnya penelitian ini. 